\title{
Tentative Schedule of ACRL Conference Meetings
}

ALA Annual Conference

San Francisco

JUNE 26-JULY 2, 1981

\section{ACRL BOARD OF DIRECTORS}

Board of Directors: Saturday, June 27, 2:00-5:30 p.m.; Tuesday, June 30, 9:30 a.m.-12:30 p.m.

Board of Directors and Budget Orientation: Saturday, June 27, 9:30 a.m.-12:30 p.m.

\section{ACRL General}

Program/Membership: Sunday, June 28, 2:004:00 p.m.

Reception: Sunday, June 28, 5:30-8:00 p.m

Chapters Orientation: Sunday, June 28, 9:3011:00 a.m.

\section{ACRL Divisional COMMITTEES}

Academic Status: Sunday, June 28, 9:30-11:00 d. m. ; Monday, June 29, 2:00-4:00 p.m.

Activity Model for 1990: Saturday, June 27, 8:00 a. $m,-12: 30$ p.m.

Audiovisual: Monday, June 29, 9:00-11:00 a.m.

Budget and Finance: Saturday, June 27, 8:0010:00 p.m.; Sunday, June $28,9: 30$ a.m. $-12: 30$ p.m.; Mlonday, June 29, 9:30 a.m.-12:30 p.m.

Chapters/Chapter Council: Sunday, June 28, 9:30-11:00 a.m.; Monday, June 29, 9:00 a.m.$12: 30$ p.m.

Conference Executive Committee-ACRL National Conference, Minneapolis, 1981: Monday, June 29, 2:00-5:30 p.m.

Conference Program Planning-Philadelphia, 1982: Saturday, June 27, 8:00-9:00 a.m.

Constitution and Bylaws: Monday, June 29, 11:30 a. m. $-12: 30$ p.m.

Continuing Education: Sunday, June 28, 9:0011:00 a.m.; Tuesday, June 30, 9:00-11:00 a.m.

Copyright (Ad Hoc): Saturday, June 27, 11:30 a.m.-12:30 p.m.; Monday, June 29, 4:30-5:30 p. m.

Copyright-Program: Monday, June 29, 2:004:00 p.m.

Legislation: Sunday, June 28, 9:30-11:00 a.m.; Tuesdav, June 30, 8:00-9:00 a.m.

Membership: Monday, June 29, 8:00-10:00 p.m.; Wednesday, July 1, 2:00-4:00 p.m.

Membership-Program: Monday, June 29, 9:3011:00 a.m.

Planning: Monday, June 29, 4:30-5:30 p.m.

Publications: Saturday, June 27, 9:30-11:00 a.m.; Monday, June 29, 11:30 a.m.-12:30 p.m.

*Meetings with an asterisk are closed meetings.
Standards and Accreditation: Sunday, June 28, 9:30 a.m.-12:30 p.m.; Monday, June 29, 4:30$5: 30$ p.m.

\section{ACRL EDITORIAL BOARDS}

Choice: Monday, June 29, 2:00-5:30 p.m.; Tuesdav, June $30,2: 00-4: 00$ p.m.

College \& Research Libraries: Monday, June 29, 2:00-4:00 p.m.

College \& Research Libraries News: Monday, June 29, 9:30-11:00 a.m.

Nonprint Media Publications: Sunday, June 28, 11:30 a.m. $-12: 30$ p.m.

Publications in Librarianship: Monday, June 29, 8:30-11:00 a.m.

\section{ACRL Discussion Groups}

Audiovisual: Tuesday, June 30, 9:30-11:00 a.m.

Cinema Librarians: Monday, June 29, 2:00-4:00 p.m.

Librarians of Library Science Collections: Mondav, June 29, 2:00-5:30 p.m.

Library Services to Extension Students: Sundav, June 28, 4:30-5:30 p.m.

Non-Bibliographic Data Bases in Academic Libraries: Mlonday, June 29, 9:30-11:00 a.m.

Personnel Officers of Large Research Libraries: Friday, June 26, 4:30-5:30 p.m.; Saturday, June 27, 8:00-9:00 a.m.; Sunday, June 28, 8:00-9:00 a.m.

Staff Development in Academic Research Libraries: Saturday, June 27, 4:30-5:30 p.m.; Sunday, June $28,4: 30-5: 30$ p.m.; Monday, June 29, 9:30-11:00 a.m.

Undergraduate Librarians: Tuesday, June 30 , 9:30 a.m. $-12: 30$ p.m.

\section{ACRL SECTIONS}

Type-of-Activity Sections Council: Monday, June 29, 8:00-10:00 p.m.

Anthropology and Sociology Section

Program: Monday, June 29, 2:00-4:00 p.m.

Art Section:

Business: Monday, June 29, 11:30 a.m.-12:30 p. $m$.

Asian and African Section

Program: Monday, June 29, 2:00-4:00 p.m.

Executive: Monday, June 29, 9:30-11:00 a.m.

Bibliographic Instruction Section

Program: Sunday, June 28, 9:30-12:00 a.m.

Executive: Monday, June 29, 8:00-10:00 p.m.

Executive Council: Saturday, June 27, 8:009:00 a.m.; Monday, June 29, 4:30-5:30 p.m.

Conference Program Planning-San Francisco, 1981: Sunday, June 28, 8:00-9:00 a.m. 
Conference Program Planning-Philadelphia, 1982: Saturday, June 27, 8:00-10:00 p.m.

Conference Program Planning-Los Angeles, 1983: Monday, June 29, 11:30 a.m.-12:30 p.m.

Continuing Education: Saturday, June 27, 9:30 a.m. $-12: 30$ p.m.

Cooperation: Saturday, June 27, 8:00-9:00 a.m.; Saturday, June $27,11: 30$ a.m. $-12: 30$ p.m.; Saturday, June 27, 9:00-11 a.m.

Cooperation-Clearinghouses (Subcommittee): Saturday, June 27, 9:00-11:00 a.m.

Education for Bibliographic Instruction: Sunday, June 28, 8:00-11:00 a.m.

Nominating: hearings Monday, June 29, 9:0011:00 a.m.*

Policy and Planning: Monday, June 29, 2:004:00 p.m.

Pre-conference Program Planning-San Francisco: Sunday, June 28, 11:30 a.m.-12:30 p.m.

Research: Saturday, June 28, 8:00-10:00 a.m.

Research-Evaluation: Sunday, June 28, 8:009:00 a.m.

College Libraries Section

Program: Monday, June 29, 9:00-11:00 a.m. Tuesday, June 30, 2:00-5:30 p.m.

Executive: Sunday, June 28, 8:00-9:00 a.m.; Tuesday, June 30, 8:00-9:00 a.m.

Conference Program Planning-Philadelphia, 1982: Monday, June 29, 2:00-5:30 p.m.

Continuing Education: Sunday, June 28, 2:004:00 p.m.; Tuesday, June 30, 9:30-11:00 a.m.

Standards and Guidelines for the College Library (Ad Hoc): Saturday, June 27, 8:00-9:00 a.m.; Monday, June 29, 8:00-9:00 a.m.

Community and Junior College Libraries Section

Program: Tuesday, June 30, 2:00-5:00 p.m.

Tour: Monday, June 29, 1:00-3:00 p.m.

Executive: Saturday, June 27, 8:00-9:00 a.m. Tuesday, June $30,8: 00-9: 00$ a.m.

Bibliography: Sunday, June 28, 9:30-11:00 a.m.

Communications: Saturday, June 27, 9:3011:30 a.m.

Instruction and Use: Sunday, June 28, 4:305:30 p.m.

Instructional Development (Ad Hoc): Sunday, June 28, 9:30-11:00 a.m.

Membership: Saturday, June 27, 9:30-11:00 a.m.

Membership/Business: Monday, June 29, 8:0010:00 p.m.

Nominating, 1981: Saturday, June 27, 2:004:00 p.m.*

Planning \& Procedures: Saturday, June 27, 11:30 a.m. $-12: 30$ p.m.

Services to Disadvantaged Students: Sunday, June 28, 8:00-9:00 a.m.

Education and Behavioral Sciences Section

Program: Monday, June 29, 9:30 a.m.-12:30 p.m.
Executive: Saturday, June 27, 8:00-10:00 p.m.

Bibliographic Instruction For Educators: Monday, June 29, 9:00-11:00 a.m.

Conference Program Planning-Philadelphia, 1982: Tuesday, June 30, 8:00-9:00 a.m.

Curriculum Materials: Saturday, June 27, 2:004:00 p.m.

Nominating, 1982: Monday, June 29, 4:30-5:30 p.m.*

Problems of Access and Control of Education Materials: Monday, June 29, 2:00-4:00 p.m.

Psychology/Psychiatry (Ad Hoc): Monday, June 29, 2:00-4:00 p.m.; Tuesday, June 30, 11:30 a. m. $-12: 30$ p.m.

Standards for Education Library Services: Monday, June 29, 2:00-5:30 p.m.

Law and Political Science Section

Membership: Sunday, June 28, 8:00-9:00 a.m.

Program: Tuesday, June 30, 2:00-4:00 p.m.

Rare Books and Manuscripts Section

Program: Saturday, June 27, 2:00-4:00 p.m.

Executive: Saturday, June 27, 9:30-11:00 a.m.; Sunday, June 28, 9:30-11:00 a.m.

Continuing Education: Saturday, June 27, 11:30 a.m.-12:30 p.m.; Saturday, June 27, 8:00-10:00 p.m.

Developing Guidelines for Marking Rare Books for Security Purposes (Ad Hoc): Sunday, June $28,11: 30$ a.m.-12:30 p.m.

Preconference Planning (Ad Hoc): Saturday, June 27, 2:00-4:00 p.m.; Saturday, June 27, 4:30-5:30 p. m.

Standards: Saturday, June 27, 4:30-5:30 p.m.; Saturday, June 27, 8:00-10:00 p.m.

Science and Technology Section

Program/Business: Saturday, June 27, 9:3011:30 a.m.

Executive: Monday, June 29, 8:00-11:00 a.m.

Goals Implementation (Ad Hoc): Sunday, June $28,4: 30-5: 30$ p.m.

Nominating, 1981: Monday, June 29, 4:30-5:30 p. m.*

Oberly Award for Bibliography in the Agricultural Sciences: Monday, June 29, 2:004:00 p. m.*

Slavic and East European Section

Membership: Monday, June 29, 4:30-5:30 p.m.

Program: Monday, June 29, 2:00-4:00 p.m.

Executive: Monday, June 29, 11:30 a.m.-12:30 p.m.

Book Dealers/Social: Monday, June 29, 7:30 p. $m$.

Conference Program Planning-Philadelphia, 1982: Sunday, June 28: 8:00-9:00 a.m.

Continuing Education: Monday, June 29, 9:3011:00 a.m.

Cyrllic Romanization and Automation (Ad Hoc): Sunday, June 28, 9:30-11:00 a.m.

Ethnic Slavic \& East European Publications in the U.S. Study (Ad Hoc): Sunday, June 28, 11:30 a. m. $-12: 30$ p.m.

Problems of Access and Control of Slavic \& 
East European Materials (Ad Hoc): Monday, June 29, 8:00-9:00 a.m.

\section{University Libraries Section}

Program: Tuesday, June 30, 2:00-5:00 p.m.

Steering: Saturday, June 27, 11:30 a.m.-12:30 p.m.; Monday, June 29, 8:00-9:00 a.m.

Western European Specialists Section

Program: Sunday, June 28, 9:30-11:30 a.m.

Membership: Tuesday, June 30, 11:30 a.m.$12: 30$ p.m.

Executive: Monday, June 29, 8:00-9:00 a.m.; Tuesday, June 30, 2:00-4:00 p.m.
Conference Program Planning-Philadelphia, 1982: Tuesday, June 30, 9:00-11:00 a.m.

Language and Literature Discussion Group: Monday, June 29, 2:00-4:00 p.m.

Planning: Monday, June 29, 9:30-11:00 a.m.

Research and Publications: Saturday, June 27, 2:00-4:00 p.m.; Monday, June 29, 9:30-11:00 a.m.

Social Science Discussion Group: Sunday, June $28,2: 00-4: 00$ p.m.

Subcommittee on Membership Survey: Tuesday, June 30, 9:00-11:00 a.m.

\section{Population Characteristics of}

\section{Academic Librarians}

\author{
Bob Carmack \\ Dean of Library Services \\ University of South Dakota \\ and \\ John N. Olsgaard \\ Documents Librarian and Archivist \\ I. D. Weeks Library \\ University of South Dakota
}

From time to time questions of the "population characteristics" of academic librarians arise which find no ready answer in the literature. With faculty, including librarians, of state-supported institutions of higher education in South Dakota now concluding their second year of a collective bargaining agreement, questions and discussions of our own experiences in South Dakota invariably turned to queries about collective bargaining in academic libraries in general. Not satisfied with information in the literature, the authors began to compile data for an article on collective bargaining in academic libraries. In so doing, some interesting population characteristics of academic librarians emerged. These "social indicators" may provide some interesting inferences about the composition of academic librarianship as a whole.

Building on the assumption that the membership of the Association of College and Research Libraries is representative of academic librarianship in general, a statistically valid stratified random sample survey of ACRL members was conducted in February-March, 1981. The survey conducted was to provide data on the current status of collective bargaining in academic libraries. Using Jean Kennelly's May, 1975, survey questionnaire on collective bargaining in academic libraries ${ }^{1}$ as a base, augmented with questions of our own, a survey instrument was prepared and administered to 700 members of ACRL. $60.4 \%$ were returned which, in and of itself, may be somewhat indicative of the interest of academic librarians in collective bargaining. Data was compiled on a general population basis but was also broken down into regional subsets. The distribution of states in each region was identical to that used in previous research. ${ }^{2}$ States included in the regions were as follows:

Northeast: Connecticut, Delaware, District of Columbia, Maine, Maryland, Massachusetts, New Hampshire, New Jersey, New York, Pennsylvania, Rhode Island, Vermont

Southeast: Alabama, Florida, Georgia, Kentucky, North Carolina, South Carolina, Tennessee, Virginia, West Virginia

Midwest: Illinois, Indiana, Iowa, Kansas, Michigan, Minnesota, Missouri, Nebraska, North Dakota, Ohio, South Dakota, Wiscon$\sin$

Southwest: Arizona, Arkansas, Louisiana, Mississippi, New Mexico, Oklahoma, Texas

'Jean R. Kennelly, "The Current Status of Academic Librarians' Involvement in Collective Bargaining: A Survey," Collective Bargaining in Higher Education, ed. Millicent D. Abell. (Chicago, American Library Association, 1976), pp. $89-90$.

${ }^{2}$ See Russell E. Bidlack, "Faculty Salaries of 62 Library Schools, 1977-78," Journal of Education for Librarianship 18:263 (Spring, 1978) and Olsgaard and Olsgaard, "Authorship in Five Library Periodicals," College and Research Libraries 41:49-53 (January, 1980). 